\title{
KEBIJAKAN ANTISIPATIF DALAM MENGHADAPI DINAMIKA HARGA BBM PADA USAHA PERIKANAN TANGKAP
}

\author{
Policy Anticipation to Cope With Fuel Price Dinamics in \\ Capture Fisheries
}

\author{
Siti Hajar Suryawati', Andrian Ramadhan ${ }^{1}$, Achmad Zamroni' dan \\ Agus Heri Purnomo ${ }^{2}$ \\ ${ }^{1}$ Balai Besar Penelitian Sosial Ekonomi Kelautan dan Perikanan \\ JI. KS. Tubun Petamburan VI Jakarta 10260 \\ Telp. (021) 53650162, Fax. (021)53650159 \\ ${ }^{2}$ Peneliti Balai Besar Litbang Pengolahan Produk dan Bioteknologi Kelautan dan Perikanan \\ Email: siti_suryawati@yahoo.com \\ Diterima 13 September 2013 - Disetujui 29 Nopember 2013
}

\begin{abstract}
ABSTRAK
Mengingat bahwa kenaikan ketersediaan energi alternatif belum dapat mengimbangi penurunan stok energi fosil, kenaikan harga bahan bakar minyak (BBM) di Indonesia tak terhindarkan. Kenaikan harga BBM tersebut diperkirakan memberikan dampak negatif terhadap biaya operasional usaha perikanan tangkap, budidaya dan pengolahan. Makalah ini bertujuan untuk: menganalisis keragaan usaha perikanan tangkap, menganalisis dampak kenaikan harga BBM terhadap usaha perikanan tangkap, dan merumuskan strategi kebijakan untuk mengantisipasi dampak kenaikan harga BBM untuk jangka pendek dan menengah pada usaha perikanan tangkap. Untuk analisis-analisis ini, dipergunakan data-data sekunder yang diperoleh dari tiga sumber utama, yaitu statistik perikanan tangkap, laporan-laporan terkait penggunaan BBM pada kapal perikanan dan laporan-laporan dampak kenaikan harga BBM pada periode sebelumnya. Hasil analisis menunjukkan: (1) Kenaikan harga BBM berdampak secara langsung proses produksi, distribusi dan konsumsi usaha perikanan; (2) Pelaku usaha perikanan melakukan usaha adaptasi dalam bentuk inovasi pembiayaan, pengurangan operasi kegiatan penangkapan, penggunaan kapal pengangkut dan penjualan langsung yang memberikan dampak lanjutan terhadap penurunan produksi dan penurunan pendapatan; (3) Strategi kebijakan yang dapat dipertimbangkan adalah: pertama, mendorong dan mempromosikan penggunaan energi alternatif; kedua, mempertimbangkan daerah over fishing sebagai daerah konservasi; ketiga, penjaminan harga ikan berkualitas; dan keempat, peningkatan kapasitas sarana dan prasarana untuk penanganan pasca panen. Kebijakan di hilir seperti penjaminan harga ikan berkualitas dan pengadaan sarana dan prasarana untuk penanganan pasca panen direkomendasikan sebagai kebijakan kreatif yang dapat memberikan dampak positif kepada pelaku usaha perikanan dan kinerja usaha perikanan secara umum.
\end{abstract}

Kata Kunci: kebijakan, bahan-bakar minyak, nelayan

\begin{abstract}
Due to the fact that the accumulating rate of alternative energies has not compensated the decrease in stock of fossil energy, fuel price increased are unavoidable. Fuel price increases are expected to bring negative impacts onoperationa costs of capture fisheries, aquaculture as well as fish processing. This paper aims to: (1) analyze the status of capture fisheries, (2) the impact of fuel price increased on capture fisheries activity and (3) formulate policy strategies to anticipate the impacts of fuel price increased in the near future and long temperiod. This analysis used secondary data that have collected from three main sources, namely Capture Fisheries Statistics, fuel consumption documents of fishing vessels and reports on the impact fuel price increase of past period. Results shows that: (1) Fuel price increase impacts directly affected to production process as well as productsdistribution and consumption; (2) Fishing vessel operators adapted to the situation through various approaches including
\end{abstract}


financial innovation, reduction in fishing activities, deploying carrier vessels, and carrying out direct selling; (3) Policy strategy options consist on several points: firstly, promoting the alternative energy; secondly, converting overexploited fishing grounds into conservation areas; thirdly, imposing quality -based pricing policies; and fourthly, increasing the capacity of post-harvest handlingfacilities and infrastructure. Downstream policies such as price guaranty based on fish quality and provision of post-harvest facilities and infrastructure are considered as creative policies, which can positively impact on fisheries performance.

Keywords: policy, fuel oil , fishers

\section{PENDAHULUAN}

Bahan Bakar Minyak (BBM) diperlukan untuk menggerakkan berbagai kegiatan produksi di sektor perikanan, baik pada usaha-usaha perikanan tangkap, budidaya maupun pengolahan. Peran penting daribahan bakar minyak padausaha tersebut adalah misalnya untuk menggerakkan mesinmesin kapal penangkap, menggerakkan kincir air pada budidaya dan mesin pendingin pada usaha pengolahan. Kebijakan menaikkan harga BBM akan berpengaruh pada proses produksi, distribusi dan pola konsumsi masyarakat. Pengaruh pada proses produksiakan meningkatkan biaya operasional dalam melakukan kegiatan penangkapan. Pengaruh pada proses distribusi adalah peningkatan biaya distribusi untuk alat transportasi, yang lebih lanjut juga akanmempengaruhi pola konsumsi ikan oleh masyarakat, baik terkait dengan kuantitas, kualitas, frekuensi, jenis ikan yang dikonsumsi.

Pada kondisi seperti ini, sektor perikanan yang mempunyai kekuatan modal besar masih dapat melakukan inovasi pembiayaan untuk mencukupi kebutuhan biaya operasional agar dapat melanjutkan kegiatan penangkapan.Sementara itu, perikanan tangkap skala kecil melakukan berbagai usaha adaptasi untuk menyesuaikan kenaikan harga BBM tersebut.

Selama ini, nelayan kecil dan kurang dari 30 Gross ton (GT) membeli BBM dengan harga umum bahkan lebih tinggi dari harga di SPBU, terutama nelayan yang berada di daerah terpencil atau jauh dari SPBU maupun SPDN. Namun demikian, strategi untuk keberlanjutan penangkapan ikan ini perlu dicari jalan keluarnya mengingat kebutuhan ikan menjadi salah satu komponen ketahanan pangan nasional. Fakta-fakta ini menunjukkan adanya sebuah permasalahan menonjol terkait dinamika harga BBM, yaitu bahwa sejauh ini belum ada kebijakan antisipatif yang secara efektif mampu meredam dampak kebijakan-kebijakan harga BBM terhadap usaha perikanan.
Tulian ini dimaksudkan untuk merumuskan sebuah rekomendasikebijakan antipatif menghadapi dinamika harga BBM pada usaha perikanan tangkap, yang didasarkan pada identifikasi dan analisis terhadap persoalan-persoalan yang terkait dengan pemunculan sebuah kebijakan antisipatif serta peluang dan kendalanya.

\section{METODOLOGI}

Penelitian ini dilaksanakan pada bulan Juli - Agustus 2013 di Kabupaten Karawang sebagai lokasi pengambilan data lapangan. Data yang digunakan meliputi data sekunder dan primer. Data sekunder berupa publikasi terkait kenaikan harga BBM dan data primer berupa data usaha perikanan. Data dikumpulkan dalam penelitian ini diperoleh melalui survey lapangan, penelusuran pustaka (desk study) berupa dokumen, literatur maupun laporan-laporan penelitian sebelumnya yang relevan dan terkait dengan topik penelitian. Data dianalisis dengan menggunakan analisis finansial serta analisis perbandingan antara sebelum dan sesudah kenaikan BBM secara deskriptif. Kemudian dilakukan analisis SWOT untuk mengetahui strategi kebijakan untuk mengantisipasi dampak dinamika harga BBM pada usaha perikanan. Selanjutnya pilihanpilihan kebijakan tersebut dipertimbangkan implementasinya dalam berbagai aspek (ekonomi, sosial, lingkungan, keuangan dan keberlanjutan) dengan analisis trade off.

\section{KERAGAAN KEBUTUHAN BBM PADA USAHA PERIKANAN TANGKAP}

Jenis BBM yang dibutuhkan pada pada usaha perikanan tangkap diantaranya adalah solar, bensin dan minyak tanah; solar dan bensin digunakan untuk untuk menggerakkan mesin kapal sedangkan minyak tanah diperlukan untuk penerangan di kapal (Suryawati et al., 2012a). Selain tergantung pada pada frekwensi daan durasi perjalanan kapal untuk operasi penangkapannya, 
kebutuhan BBM juga ditentukan oleh karakteristik kapal yang digunakan.Kapal-kapal berukuran kurang dari 30 GT dan yang berukuran lebih dari 30 GT mempunyai karakteristik berbeda dalam hal: (1) jenis alat tangkap yang digunakan,(2) musim penangkapan,(3) fishing ground, (4) jumlah trip, (5) status dan peran (pemilik kapal, nakhoda, dan ABK), (6) distribusi pendapatan (bagi hasil atau gaji); dan (7) jenis tangkapan.

Dengan perbedaan karakteristik tersebut di atas, hasil analisis menunjukkan bahwa ratarata kebutuhan BBM untuk kapal penangkap berukuran kurang dari 20 GT adalah 2.530 liter/ tahun sedangkan rata-rata kebutuhan BBM untuk kapal penangkap berukuran lebih dari 20 GT sampai 300 GT adalah 64.000 liter/tahun (Tabel 1). Hasil analisis juga menunjukkan adanya perbedaan dalam persentase kebutuhan biaya BBM dalam struktur biaya operasional bagi kapal-kapal berukuran besar dan kapal-kapal berukuran kecil. Pada kapal-kapal berukuran lebih dari 100 GT biaya operasional untuk komponen BBM mencapai $84 \%$ sedang untuk kapal ukuran 10 - 20 GT adalah 28\% (Tabel 2).

Terlepas dari perbedaan dalam hal kebutuhan BBM, nelayan dengan kapal berbagai karakteristik tersebut di atas memiliki kesamaan dalam hal pola pendekatan yang diterapkannya untuk menyiasati permasalahan harga, akses dan distribusi. Pola yang diterapkan oleh nelayan untuk mendapatkan akses yang lebih baik dan untuk menekan pengeluaran untuk BBM dan biaya operasional lain pada umumnya mencakup satu atau lebih dari pilihan-pilihan berikut: (1) mendaratkan ikan di tempat terdekat dengan fishing ground, (2) menjual ikan secara langsung dengan pembeli yang menerima berbagai jenisikan dengan berbagai kualitas, dan (3) menjual ikan di tengah laut untuk mengurangi biaya-biaya untuk pelelangan dan biaya tambat kapal.

Meski untuk masing-masing kapal hanya mengkonsumsi BBM dalam jumlah relative lebih sedikit (Tabel 2), secara total nasional kapal-kapal berukuran kecil membutuhkan pasok yang lebih besar. Perahu-perahu perikanan tangkap berukuran < 5 GT merupakan kelompok konsumen BBM terbesar dibandingkan dengan kelompok kapal yang lainnya. Kelompok kapal berukuran lebih dari 300 GT secara total nasional mengkonsumsi BBM relatif lebih sedikit; hal ini karenajumlah kapal tersebut sedikit dibandingkan kelompok kapal dengan kapasitas kurang dari 5 GT.

Tabel 1. Konsumsi BBM untuk Kapal Perikanan per Tahun.

Table 1. Fuel Consumption for Fishing Vessels by Year.

\begin{tabular}{|c|c|c|c|c|}
\hline No & $\begin{array}{l}\text { Jenis Kapal/ } \\
\text { Type of vessel }\end{array}$ & Liter / trip & $\begin{array}{l}\text { Hari/trip } \\
\text { Day / trip }\end{array}$ & $\begin{array}{l}\text { Trip / tahun } \\
\text { Trip / Year }\end{array}$ \\
\hline \multirow[t]{2}{*}{1} & Premium (Gasoline) & & & \\
\hline & $\begin{array}{l}\text { Perahu motor temple } \\
\text { (Outboard engined) }\end{array}$ & 8 & 1 & 200 \\
\hline \multirow[t]{4}{*}{2} & Minyak Solar (Diesel) & & & \\
\hline & $\begin{array}{l}\text { Kapal motor (engined } \\
\text { vessel) <5 GT }\end{array}$ & 20 & 3 & 150 \\
\hline & $\begin{array}{l}\text { Kapal motor (Engined } \\
\text { vessel) 5-10 GT }\end{array}$ & 24 & 5 & 125 \\
\hline & $\begin{array}{l}\text { Kapal motor (Engined } \\
\text { vessel) } 15 \mathrm{GT}\end{array}$ & 36 & 15 & 70 \\
\hline \multirow[t]{6}{*}{3} & $\begin{array}{l}\text { Kapal } 20-300 \mathrm{GT} \\
(\text { Engined vesse/s) 20-30 GT }\end{array}$ & & & \\
\hline & $20-30 \mathrm{GT}$ & 5,000 & 35 & 8 \\
\hline & $30-50 \mathrm{GT}$ & 8,000 & 40 & 8 \\
\hline & $50-100 \mathrm{GT}$ & 12,000 & 90 & 3 \\
\hline & $100-200 \mathrm{GT}$ & 25,000 & 90 & 3 \\
\hline & $200-300 \mathrm{GT}$ & 35,000 & 120 & 3 \\
\hline
\end{tabular}

Sumber: Anonim (2001), Suryawati et al., (2012a) / Source: Anonymous (2001), Suryawati et al., (2012a) 
Tabel 2. Keragaan Finansial Usaha Perikanan Tangkap dalam Skala Usaha yang Berbeda Menurut GT Kapal.

Table 2. Financial Figure of Fishing Operation According to Variuos Bussines Scale Based on Vessel Weight.

Satuan: Rp. 000,- per tahun / Unit: Rp 000 per year

\begin{tabular}{|c|c|c|c|c|c|c|c|c|}
\hline \multirow[b]{2}{*}{ No } & \multirow[b]{2}{*}{ Komponen//tem } & \multicolumn{7}{|c|}{ Ukuran Kapal /Size of Vessel } \\
\hline & & $<5 \mathrm{GT}$ & $5-10 \mathrm{GT}$ & $\begin{array}{c}10-20 \\
\text { GT }\end{array}$ & $\begin{array}{c}20-30 \\
\text { GT }\end{array}$ & $30-50 \mathrm{GT}$ & $50-100 \mathrm{GT}$ & $>100 \mathrm{GT}$ \\
\hline A & Biaya Investasi/ Investment & & & & & & & \\
\hline 1. & Kapal/Vessel & 25,000 & 120,000 & 200,000 & 500,000 & 759,000 & 860,000 & $2,897,500$ \\
\hline 2. & Mesin/Engine & 4,200 & 40,000 & 100,000 & 165,000 & 228,750 & 322,000 & $1,092,500$ \\
\hline 3. & Peralatan tangkap /Gear & 1,100 & 3,500 & 30,000 & 45,000 & 55,000 & 185,000 & 617,500 \\
\hline \multirow[t]{3}{*}{4.} & $\begin{array}{l}\text { Perlengkapan pendukung/ } \\
\text { Supporting item }\end{array}$ & 1,212 & 10,400 & 25,000 & 50,000 & 79,825 & 35,000 & 142,500 \\
\hline & Sub jumlah/Sub Total & 31,512 & 173,900 & 355,000 & 760,000 & $1,122,575$ & $1,402,000$ & $4,750,000$ \\
\hline & Biaya tidak tetap /Variable Cost & & & & & & & \\
\hline 1 & Bahan bakar/Fuel & 19,440 & 12,960 & 13,140 & 148,500 & 288,000 & 270,000 & $11,070,000$ \\
\hline 2 & Oli/Lubricant oil & 1,104 & 1,380 & 3,450 & 4,140 & 7,360 & 6,440 & $1,099,400$ \\
\hline 3 & Minyak tanah /Kerosene & - & 1,800 & 1,440 & 6,000 & 8,000 & 28,000 & - \\
\hline 4 & Ransum /Food & 12,000 & 14,400 & 15,420 & 15,000 & 104,000 & 90,000 & 900,000 \\
\hline 5 & Es balok/ curah /Crushed ice & - & 2,520 & 9,000 & 13,500 & 48,000 & 36,000 & - \\
\hline 6 & Garam /Salt & - & 162 & 300 & 420 & 600 & - & - \\
\hline \multirow[t]{3}{*}{7} & Air bersih/Water clean & - & 1,260 & 2,813 & 2,700 & 6,800 & 15,000 & 100,000 \\
\hline & Sub jumlah/Sub total & 32,544 & 34,482 & 45,563 & 190,260 & 462,760 & 445,440 & $13,169,400$ \\
\hline & Biaya tetap/Fixed cost & & & & & & & \\
\hline 1 & $\begin{array}{l}\text { Perbaikan kapal/Vessel } \\
\text { maintenance }\end{array}$ & 2,500 & 12,000 & 20,000 & 50,000 & 75,900 & 86,000 & 289,750 \\
\hline 2 & $\begin{array}{l}\text { Perbaikan mesin/Engine } \\
\text { maintenance }\end{array}$ & 420 & 4,000 & 10,000 & 16,500 & 22,875 & 32,200 & 109,250 \\
\hline 3 & $\begin{array}{l}\text { Perbaikan alat tangkap /Gear } \\
\text { maintenance }\end{array}$ & 220 & 700 & 6,000 & 9,000 & 11,000 & 37,000 & 30,875 \\
\hline 4 & $\begin{array}{l}\text { Biaya perijinan, pajak, retribusi/ } \\
\text { Permit, tx, retribution }\end{array}$ & 1,812 & 2,430 & 3,278 & 22,800 & 42,825 & 60,000 & - \\
\hline \multirow[t]{3}{*}{5} & Penyusutan /Depreciation & 3,151 & 17,390 & 35,500 & 76,000 & 112,258 & 140,200 & - \\
\hline & Sub jumlah / Sub total & 8,103 & 36,520 & 74,778 & 174,300 & 264,858 & 355,400 & 429,875 \\
\hline & $\begin{array}{l}\text { Total biaya/ Arus keluar / } \\
\text { Total Cost }\end{array}$ & 40,6470 & 71,002 & 120,340 & 364,560 & 727,618 & 800,840 & $13,599,275$ \\
\hline B & Penerimaan /Revenue & & & & & & & \\
\hline 1. & Hasil tangkapan/Catch & 72,500 & 97,200 & 131,100 & 912,000 & $1,713,000$ & 2,400000 & $16,250,000$ \\
\hline \multirow[t]{2}{*}{ c. } & $\begin{array}{l}\text { Total penerimaan Total } \\
\text { revenue }\end{array}$ & 72,500 & 97,200 & 131,100 & 912,000 & $1,713,000$ & $2,400,000$ & $16,250,000$ \\
\hline & $\mathrm{R} / \mathrm{C}$ ratio & 1.78 & 1.37 & 1.09 & 2.50 & 2.35 & 3.00 & 1.19 \\
\hline
\end{tabular}

Sumber: Data sekunder diolah (2013) / Source: Secondary data analyzed (2013)

Untuk seluruh perahu dan kapal penangkap berukuran kecil (<30 GT), total kebutuhan BBM nasional pada Tahun 2013 adalah 2,1 juta liter. Nilai tersebut masih di bawah kuota BBM besubsidi yang diberikan oleh pemerintah, yaitu sebanyak 2,5 juta liter. Faktor distribusi telah menyebabkan tidak terserapnya kuota tersebut; selama ini, banyak di antara kelompok motor tempel, dan kapal berukuran kurang dari 5 GT dan 5-10 GT yang membeli BBM dengan harga non-subsidi karena alasan buruknya distribusi.Kondisi ini bisa menjadi pertimbangan dalam distribusi BBM perikanan untuk lebih memperhatikan nelayan skala kecil terutama perahu < 5 GT. Kondisi sebaliknya terjadi pada kapal-kapal berukuran 30 GT sampai lebih dari 300 GT yang mempunyai kemudahan untuk memperoleh BBM bersubsidi karena tempat pendaratan ikan dekat dengan SPDN (Tabel 3). 
Tabel 3. Perbandingan Jumlah Konsumsi BBM pada Masing-Masing Kelompok Kapal. Table 3. Comparison of Fuel Consumption of Different Vessel.

\begin{tabular}{|c|c|c|c|c|c|c|c|}
\hline $\begin{array}{l}\text { Jenis Kapal/ } \\
\text { Vessel Type }\end{array}$ & $\begin{array}{l}\text { Jumlah } \\
\text { Kapal Secara } \\
\text { Nasional/ } \\
\text { Total Number } \\
\text { of Vessel, } \\
\text { Nationally }\end{array}$ & $\%$ & $\begin{array}{l}\text { Kebutuhan BBM/ } \\
\text { Tahun (Liter/ } \\
\text { Tahun/Kapal) } \\
\text { Fuel Need (Litre/ } \\
\text { Vessel/year) }\end{array}$ & $\begin{array}{l}\text { Jumlah Total } \\
\text { Kebutuhan } \\
\text { BBM (liter)/ } \\
\text { Total Fuel Need } \\
\text { (litre) }\end{array}$ & $\begin{array}{l}\text { Jumlah } \\
\text { Trip/ } \\
\text { Tahun } \\
\text { Total } \\
\text { Trip / } \\
\text { Year }\end{array}$ & $\begin{array}{l}\text { \% konsumen } \\
\text { BBM/ } \\
\text { Percentge } \\
\text { of Fuel } \\
\text { Consumption }\end{array}$ & $\begin{array}{c}\text { Status } \\
\text { Subsidi/ } \\
\text { Subsidy Status }\end{array}$ \\
\hline $\begin{array}{l}\text { Motor tempel/ } \\
\text { Outboard } \\
\text { engined }\end{array}$ & 225,786 & 54.95 & 2,000 & $451,572,000$ & 200 & 26.16 & $\begin{array}{l}\text { Tanpa subsid / } \\
\text { No subsidiy }\end{array}$ \\
\hline$<5 \mathrm{GT}$ & 123,748 & 30.12 & 4,320 & $534,591,360$ & 216 & 30.97 & $\begin{array}{l}\text { Tanpa subsidi / } \\
\text { No subsidy }\end{array}$ \\
\hline $5-10 \mathrm{GT}$ & 35,837 & 8.72 & 2,880 & $103,210,560$ & 36 & 5.98 & $\begin{array}{l}\text { Tanpa subsidi / } \\
\text { No subsidy }\end{array}$ \\
\hline $10-20 \mathrm{GT}$ & 13,201 & 3.21 & 9,040 & 1726402099 & 15 & 6.91 & Subsidi /Subsidized \\
\hline $20-30 \mathrm{GT}$ & 8,022 & 1.95 & 33,000 & $264,726,000$ & 8 & 15.33 & Subsidi /Subsidized \\
\hline $30-50 \mathrm{GT}$ & 914 & 0.22 & 64,000 & $58,496,000$ & 8 & 3.39 & Subsidi /Subsidized \\
\hline $50-100 \mathrm{GT}$ & 1,801 & 0.44 & 58,823 & $105,940,223$ & 4 & 6.14 & Subsidi /Subsidized \\
\hline $100-200 \mathrm{GT}$ & 1,204 & 0.29 & 73,529 & $88,528,916$ & 4 & 5.13 & Subsidi /Subsidized \\
\hline Total & 410,867 & & & $1,726,402,099$ & & & \\
\hline
\end{tabular}

Sumber: Data sekunder diolah (2013) / Source: Secondary data processed (2013)

Permasalahan terkait subsidi BBM dengan skema seperti terlihat pada Tabel 2 pada kenyataannya bukan satu-satunya permasalahan. Kenyataannya, pada dasarnya subsidi BBM tidak hanya diperlukan untuk kapal berukuran kecl melainkan juga untuk kaal berukuran besar. Pemberian subsidi BBM untuk kapal berukuran kurang dari 30 GT terutama diperlukan untuk mempertahankan kecukupan kebutuhan protein secara nasional, mempertahankan pasar domestik dan mengurangi tingkat kemiskinan. Sementara itu, pemberian subsidi BBM untuk kapal di atas 30 GT sangat penting untuk mempertahankan atau meningkatkan pendapatan nasional, kedaulatan sumber daya kelautan dan perikanan dan dapat meminimalisasi praktek illegal fishing.

\section{PREDIKSI DAMPAK PERUBAHAN BESARAN SUBSIDI BBM PADA USAHA PERIKANAN TANGKAP}

BBM merupakan komponen penting di dalam usaha perikanan tangkap. Proporsi pengeluaran usaha perikanan tangkap untuk BBM mencapai $64 \%$ dari total biaya operasional dan $42 \%$ dari total biaya (biaya operasional dan biaya tetap). Hal ini menyebabkan besarnya pengaruh kenaikan harga BBM terhadap kinerja atau keragaan usaha perikanan tangkap laut. Terlebih harga beli BBM pada nelayan skala kecil dengan kapal berukuran kurang dari 10 GT lebih tinggi dari harga yang ditetapkan (Tabel 4). Saat ini, nelayan skala kecil membeli BBM dengan harga antara Rp 5.000 Rp 7.000 (BBPSEKP, 2012).

Pada tahun 2005, ketika BBM dinaikkan sebanyak dua kali oleh pemerintah, laju inflasi tahunan saat itu sangat tinggi yaitu sebesar $17.11 \%$. Kenaikan harga BBM terjadi pada bulan Maret 2005 mulai dari Rp1.810 menjadi Rp 2.400 (24.5\%) dan pada bulan Oktober naik dari Rp 2.400 menjadi Rp 4.500 (87.5\%). Total kenaikan harga BBM yang terjadi adalah Rp 2.690 (148.61\%). Pada tahun 2008 BBM kembali mengalami kenaikan per 1 Oktober sebesar $33.33 \%$ dari Rp 4.500 menjadi Rp 6.000 . Namun demikian, harga BBM kali ini turun ke harga awal per 14 Januari 2009.

Bila dilihat lebih rinci, kenaikan harga barang tertinggi pada tahun 2005 terjadi pada kelompok pengeluaran transportasi, komunikasi dan jasa keuangan yaitu $44.75 \%$.Kelompok pengeluaran tertinggi lainnya adalah perumahan, air, listrik, gas dan bahan bakar sebesar $13.94 \%$, bahan makanan $13.91 \%$ dan makanan jadi sebesar $13.74 \%$. Sementara pada kenaikan harga BBM tahun 2008 justru kenaikan sangat tinggi tercatat pada harga bahan makanan yaitu $16.35 \%$, sedangkan pengeluaran transportasi, komunikasi dan jasa keuangan naik hanya sebesar $7.49 \%$ (Tabel 4). 
Tabel 4. Harga dan Proporsi BBM menurut Ukuran Kapal. Table 4. Fuel Price and its Proportion by Vessel Size.

\begin{tabular}{|c|c|c|c|c|}
\hline $\begin{array}{l}\text { Ukuran Kapal / } \\
\text { Vessel Size (GT) }\end{array}$ & $\begin{array}{c}\text { Harga Beli/ } \\
\text { Purchasing Price } \\
\text { (Rp) }\end{array}$ & $\begin{array}{l}\text { Biaya BBM Pertahun/ } \\
\text { Annual Fuel Cost (Rp) }\end{array}$ & $\begin{array}{c}\text { Biaya Operasionalper } \\
\text { Tahun (Annual } \\
\text { Operational Cost) } \\
\text { (Rp) }\end{array}$ & $\begin{array}{c}\text { Proporsi Biaya BBM } \\
\text { Terhadap Biaya } \\
\text { Operasional/ Ratio of } \\
\text { Fuel Cost to Operational } \\
\text { Cost (\%) }\end{array}$ \\
\hline$<5$ & 5,500 & $23,760,000$ & $36,864,000$ & 64 \\
\hline $5-10$ & 5,500 & $15,840,000$ & $37,362,000$ & 42 \\
\hline $10-20$ & 4,500 & $40,680,000$ & $82,280,000$ & 49 \\
\hline $20-30$ & 4,500 & $148,500,000$ & $190,260,000$ & 78 \\
\hline $30-50$ & 8,200 & $524,800,000$ & $699,560,000$ & 75 \\
\hline $50-100$ & 8,200 & $492,000,000$ & $667,440,000$ & 74 \\
\hline $100-200$ & 8,200 & $3,926,790,000$ & $5,599,365,000$ & 63 \\
\hline
\end{tabular}

Sumber : BBPSEKP (2012); Karto (2008); Pujo et al., (2012); Erfan (2008); Suryawati et al., (2012a)/

Source: BBPSEKP (2012); Karto (2008); Pujo et al., (2012); Erfan (2008); Suryawati et al., (2012a)

Tabel 5. Inflasi Harga-Harga Barang pada Tahun Terjadinya Kenaikan BBM. Table 5. Price Inflation of Various Goods in Years of Fuel Price Increases.

\begin{tabular}{lrr} 
& \multicolumn{2}{c}{ Tahun /Year } \\
& 2005 & 2008 \\
\hline Kenaikan harga BBM/fuel price increase(\%) & 148.61 & 33.33 \\
Inflasi gabungan /Composite inflation (\%) & 17.11 & 11.06 \\
Inflasi bahan makanan/Food inflation) & 13.91 & 16.35 \\
Inflasi makanan jadi, minuman, rokok, dan tembakau/ & 13.71 & 12.53 \\
Inflation of drinks, cigarette and tobacco) & & 10.92 \\
Inflasi perumahan, air, listrik, gas, dan bahan bakar/ & 13.94 & 7.33 \\
Inflation of housing, water, gas and fuel) & & 7.96 \\
Sandang /Clothing) & 6.92 & 6.66 \\
Kesehatan/Health & 6.13 & 7.49 \\
Pendidikan, rekreasi dan olah raga/Recreation and sport) & 8.24 & \\
Transport dan komunikasi dan jasa keuangan / & 44.75 & \\
Trasportation, communication and financial services) & & \\
\hline
\end{tabular}

Sumber : BPS (2012) / Source: BPS (2012)

Melakukan prediksi kondisi usaha perikanan tangkap setelah terjadinya kenaikan BBM perlu memperkirakan kenaikan harga-harga pada komponen penyusun biaya operasional. Kenaikan biaya untuk ransum, garam, es balok dan air bersih diprediksi dipengaruhi kenaikan harga rata-rata untuk kelompok bahan makanan dan bahan makanan jadi, minuman, rokok dan tembakau yaitu sebesar 14,13 persen. Kenaikan harga oli diprediksi atas kenaikan rata-rata harga kelompok perumahan, air, listrik, gas dan bahan bakar yaitu sebesar 12,43 persen. Kenaikan biaya-biaya tersebut diperoleh berdasarkan perhitungan biaya operasional sebelum kenaikan harga BBM (Tabel 6) dan prediksi biaya operasional setelah kebijakan kenaikan BBM dengan asumsi kenaikan harga BBM yang ditetapkan oleh pemerintah menjadi Rp. 6.500/ liter (Tabel 7).

Kenaikan harga BBM solar mengakibatkan penurunan pada pendapatan usaha nelayan, terutama karena meningkatnya biaya operasional. Komponen-komponen biaya operasional yang meningkat akibat kenaikan harga BBM adalah biaya konsumsi ${ }^{2}$, kenaikan pada biaya pembelian air $^{3}$, dan kenaikan pada biaya pembelian solar.

\footnotetext{
2Semua barang kebutuhan meningkat akibat adanya kenaikan harga bahan bakar minyak ${ }^{3}$ Kenaikan harga BBM menyebabkan biaya transportasi yang lebih besar untuk mengangkut air dari tempat pembelian ke tempat bersandarnya kapal
} 
Secara rata-rata, kenaikan harga pada komponenkomponen tersebut menyebabkan kenaikan biaya operasional sebesar lebih dari 33 persen. Perhitungan kenaikan harga komponen dalam biaya operasional tersebut diperoleh berdasarkan perhitungan kenaikan harga-harga untuk komponen tersebut pada Tabel 6 dan 7 .

Penurunan daya beli masyarakat secara umum dapat menyebabkan menurunnya permintaan ikan. Pada komoditas ikan yang berorientasi ekspor, harga ikan ditentukan oleh pasar internasional sehingga belum tentu mengalami kenaikan.Berdasarkan kondisi tersebut, maka proyeksi penerimaan usaha setelah kenaikan dibuat atas dua kondisi yaitu tidak mengalami kenaikan dan naik sebesar inflasi bahan makanan dari dua kali pengalaman kenaikan BBM sebelumnya yaitu 15,13\% (Tabel 8).

Tabel 6. Biaya Operasional Usaha Perikanan Tangkap Sebelum Kenaikan Harga BBM. Table 6. Operational Cost of Fishing Operation Before the Fuel Price Increase.

Satuan: Rp. 000,- per tahun / Unit: Rp 000 per year

\begin{tabular}{|c|c|c|c|c|c|c|c|c|}
\hline \multirow{2}{*}{ No } & \multirow{2}{*}{$\begin{array}{c}\text { Biaya Operasional/ } \\
\text { Operational Cost }\end{array}$} & \multicolumn{7}{|c|}{ Ukuran Kapal/Vessel Size in GT } \\
\hline & & $<5$ & $5-10$ & $10-20$ & $20-30$ & $30-50$ & $50-100$ & $>100$ \\
\hline 1 & Bahan bakar/Fuel & 23,760 & 15,840 & 40,680 & 148,500 & 524,800 & 492,000 & $3,499,965$ \\
\hline 2 & Oli/Lubricant & 1,104 & 1,380 & 3,450 & 4,140 & 7,360 & 6,440 & $1,099,400$ \\
\hline 3 & $\begin{array}{l}\text { Minyak Tanah/ } \\
\text { Kerosene }\end{array}$ & - & 1,800 & 1,440 & 6,000 & 8,000 & 28,000 & - \\
\hline 4 & Ransum/Food & 12,000 & 14,400 & 20,560 & 15,000 & 104,000 & 90,000 & 900,000 \\
\hline 5 & $\begin{array}{l}\text { Es balok/Curah } \\
\text { Crushed ice }\end{array}$ & - & 2,520 & 12,000 & 13,500 & 48,000 & 36,000 & - \\
\hline 6 & Garam/Salt & - & 162 & 400 & 420 & 600 & - & - \\
\hline \multirow[t]{2}{*}{7} & $\begin{array}{l}\text { Air bersih/Clean } \\
\text { Water }\end{array}$ & - & 1,260 & 3,750 & 2,700 & 6,800 & 15,000 & 100,000 \\
\hline & Jumlah/Total & 36,864 & 37,362 & 82,280 & 190,260 & 699,560 & 667,440 & $5,599,365$ \\
\hline
\end{tabular}

Sumber: Data diolah (2013) / Source: Processed data (2013)

Tabel 7. Prediksi Biaya Operasional Usaha Perikanan Tangkap Setelah Kenaikan BBM. Table 7. Operational Cost Predicted of Fishing Operation After Fuel Price Increase.

Satuan:Rp. 000,- per tahun / Unit: Rp 000 per year

\begin{tabular}{|c|c|c|c|c|c|c|c|c|}
\hline \multirow{2}{*}{ No } & \multirow{2}{*}{$\begin{array}{c}\text { Biaya Operasional/ } \\
\text { Operational Cost }\end{array}$} & \multicolumn{7}{|c|}{ Ukuran Kapal/Vessel Size in GT } \\
\hline & & $<5$ & $5-10$ & $10-20$ & $20-30$ & $30-50$ & $50-100$ & $>100$ \\
\hline 1 & Bahan Bakar/Fuel & 30,240 & 20,160 & 49,720 & 181,500 & 588,800 & 552,000 & $3,926,790$ \\
\hline 2 & Oli/Lubricant & 1,295 & 1,619 & 4,047 & 4,857 & 8,634 & 7,555 & $1,289,796$ \\
\hline 3 & $\begin{array}{l}\text { Minyak Tanah/ } \\
\text { Kerosene }\end{array}$ & - & 1,800 & 1,440 & 6,000 & 8,000 & 28,000 & - \\
\hline 4 & Ransum/Food & 13,695 & 16,434 & 23,464 & 17,119 & 118,690 & 102,712 & $1,027,125$ \\
\hline 5 & $\begin{array}{l}\text { Es Balok/Curah/ } \\
\text { Crushed Ice }\end{array}$ & - & 2,876 & 13,695 & 15,407 & 54,780 & 41,085 & - \\
\hline 6 & Garam/Salt & - & 184 & 342 & 479 & 684 & - & - \\
\hline \multirow[t]{3}{*}{7} & $\begin{array}{l}\text { Air bersih/ } \\
\text { Clean water }\end{array}$ & - & 1,438 & 4,279 & 3,081 & 7,760 & 17,118 & 114,125 \\
\hline & Jumlah/Total & 45,230 & 44,511 & 96,988 & 228,443 & 787,349 & 748,471 & $6,357,836$ \\
\hline & $\begin{array}{l}\text { \% Kenaikan Biaya } \\
\text { Operasional/ } \\
\% \text { Increase of } \\
\text { Operational Cost }\end{array}$ & 22.69 & 19.14 & 17.88 & 20.07 & 12.55 & 12.14 & 13.55 \\
\hline
\end{tabular}

Sumber: Data sekunder diolah (2013) / Source: Secondary data analyzed (2013) 
Tabel 8. Penerimaan Kotor Usaha Perikanan Tangkap Menurut Ukuran Kapal Sebelum dan Sesudah Kenaikan Harga BBM.

Table 8. Gross Revenue of Fishing Operation by Vessel Size Before Fuel Price Increase.

\begin{tabular}{|c|c|c|}
\hline $\begin{array}{c}\text { Ukuran Kapal/ } \\
\text { Vessel Size }\end{array}$ & $\begin{array}{c}\text { Penerimaan saat ini/ } \\
\text { Tanpa Kenaikan Harga Jual Ikan } \\
\text { per Tahun (Rp)/ } \\
\text { Present Annual Revenue Without } \\
\text { Increase in Fish Selling Price } \\
\text { (Rp) }\end{array}$ & $\begin{array}{c}\text { Prediksi Penerimaan Dengan Kenaikan Harga } \\
\text { Jual Ikan Pasca Kenaikan Harga BBM per } \\
\text { Tahun (Rp)/ } \\
\text { Predicion Annual Revenue With Increased of } \\
\text { Fish Selling Price After Fuel Price Increase } \\
\text { (Rp) }\end{array}$ \\
\hline$<5 \mathrm{GT}$ & $72,500,000$ & $83,469,250$ \\
\hline 5-10 GT & $97,200,000$ & $111,906,360$ \\
\hline 10-20 GT & $367,000,000$ & $422,527,100$ \\
\hline 20-30 GT & $912,000,000$ & $1,049,985,600$ \\
\hline 30-50 GT & $1,713,000,000$ & $1,972,176,900$ \\
\hline 50-100 GT & $1,900,000,000$ & $2,187,470,000$ \\
\hline $100-200 \mathrm{GT}$ & $8,750,000,000$ & $10,073,875,000$ \\
\hline
\end{tabular}

Sumber: Data sekunder diolah (2013) / Source: Secondary data analyzed (2013)

Dampak kenaikan harga BBM dapat mengakibatkan dua kemungkinan yaitu terjadi penurunan revenue cost ratio( $\mathrm{R} / \mathrm{C}$ ratio) atau sebaliknya. Nilai $\mathrm{R} / \mathrm{C}$ ratio akan mengalami penurunan rata-rata 11,54 pesen jika kenaikan harga BBM tidak diikuti dengan harga jual ikan di tingkat produsen. Apabila harga ikan mengalami peningkatan sebesar 15,13 persen, maka secara rata-rata $\mathrm{R} / \mathrm{C}$ ratio naik tidak signifikan yaitu hanya sebesar 0,29 persen. Kondisi ini memberi arti bahwa usaha perikanan secara umum dapat menyesuaikan diri dengan kondisi yang baru bila terjadi peningkatan harga jual ikan rata-rata $15 \%$. Ada dua kategori usaha yang sebetulnya tetap akan mengalami penurunan $\mathrm{R} / \mathrm{C}$ ratio yaitu pada kelompok usaha kecil dibawah 5 GT dan kelompok di atas 100 GT. Sementara itu, kelompok usaha lainnya rata-rata tercatat naik sebesar
3,84 pesen. Hal yang perlu dicatat adalah kenaikan ini merupakan kenaikan rata-rata dalam setahun bukan kenaikan dalam jangka pendek yang sangat dipengaruhi oleh faktor-faktor lainnya (Tabel 9).

Hal penting yang perlu di perhatikan dari setiap perubahan kebijakan harga BBM adalah terjadinya gejolak laju inflasi dalam jangka waktu tertentu sebelum kembali pada laju inflasi secara normal yang umum disebut dengan persentase inflasi. Pada tahun 2008, inflasi pada bulan-bulan setelah kenaikan BBM yaitu Mei, Juni dan Juli, total inflasi mencapai 5,24\%. Sementara inflasi normal pada bulan-bulan sama di tahun 2006 - 2011 rata-rata hanya sebesar $1,42 \%$.

Dampak secara lebih spesifik pada usaha perikanan adalah menurunnya kemampuan nelayan dalam menyediakan modal perbekalan melaut.

Tabel 9. Prediksi Perubahan Nilai R/C Setelah Kenaikan Harga BBM Tanpa Kenaikan Harga Jual Ikan per Tahun.

Table 9. Prediction Changes in R/C Values After Increased in Fuel Price Without Fish Selling Price Increased Per Year.

\begin{tabular}{|c|c|c|c|c|}
\hline $\begin{array}{c}\text { Ukuran } \\
\text { Kapal/ } \\
\text { Vessel Size }\end{array}$ & $\begin{array}{c}\text { Prediksi } \\
\text { Penerimaan 1/ } \\
1^{\text {st }} \text { Prediction of } \\
\text { Revenue }\end{array}$ & $\begin{array}{c}\text { Prediksi Biaya } \\
\text { Operasional Pasca } \\
\text { Kenaikan BBM/ } \\
\text { Prediction on } \\
\text { Operational Cost Post } \\
\text { Fuel Price Increased }\end{array}$ & $\begin{array}{c}\text { Prediksi R/C 1/ } \\
1^{\text {st }} \text { Prediction R/C }\end{array}$ & $\begin{array}{c}\text { Perubahan Nilai } \\
\text { R/CI } \\
\text { Changes in } R / C\end{array}$ \\
\hline$<5 \mathrm{GT}$ & $72,500,000$ & $53,608,125$ & 1.36 & -0.25 \\
\hline 5-10 GT & $97,200,000$ & $71,399,459$ & 1.37 & -0.15 \\
\hline 10-20 GT & $367,000,000$ & $179,051,820$ & 2.07 & -0.19 \\
\hline $20-30 \mathrm{GT}$ & $912,000,000$ & $406,192,941$ & 2.26 & -0.24 \\
\hline $30-50 \mathrm{GT}$ & $1,713,000,000$ & $1,058,686,797$ & 1.63 & -0.13 \\
\hline $50-100 \mathrm{GT}$ & $1,900,000,000$ & $1,098,558,296$ & 1.74 & -0.14 \\
\hline 100-200 GT & $28,750,000,000$ & $6,787,711,960$ & 1.29 & -0.04 \\
\hline
\end{tabular}

Sumber: Data sekunder diolah (2013) / Source: Secondary data analyzed(2013) 
Tabel 10. Prediksi Perubahan Nilai R/C Setelah Kenaikan Harga BBM dengan Kenaikan Harga Jual Ikan per Tahun.

Table 10. Prediction on R/C Changes After Fuel Price Increased With Increased of Fish Selling Price.

\begin{tabular}{ccccc}
\hline $\begin{array}{c}\text { Ukuran } \\
\text { Kapal/ } \\
\text { Vessel Size }\end{array}$ & $\begin{array}{c}\text { Prediksi } \\
\text { Penerimaan 2/ } \\
2^{\text {nd }} \text { Predicton of } \\
\text { Revenue }\end{array}$ & $\begin{array}{c}\text { Prediksi Biaya } \\
\text { Operasional Pasca } \\
\text { Kenaikan BBM/ } \\
\text { Prediction Operational } \\
\text { Cost After Fuel Price } \\
\text { Increase }\end{array}$ & $\begin{array}{c}\text { Prediksi R/C 2/ } \\
2^{\text {nd }} \text { Prediction } \\
\text { R/C }\end{array}$ & $\begin{array}{c}\text { Perubahan Nilai } \\
\text { R/C / }\end{array}$ \\
\hline < 5 GT & $83,469,250$ & $53,608,125$ & 1.57 & -0.05 \\
5-10 GT & $111,906,360$ & 71,399459 & 1.58 & 0.05 \\
10-20 GT & $422,527,100$ & $179,051,820$ & 2.38 & 0.13 \\
20-30 GT & $1,049,985,600$ & $406,192,941$ & 2.61 & 0.11 \\
30-50 GT & $1,972,176,900$ & $1,058,686,797$ & 1.87 & 0.11 \\
50-100 GT & $2,187,470,000$ & $1,098,558,296$ & 2.00 & 0.12 \\
100-200 GT & $29,317,375,000$ & $6,787,711,960$ & 1.48 & 0.16 \\
\hline
\end{tabular}

Sumber: Data sekunder diolah (2013) / Source: Processed secondary data (2013)

Akibatnya, nelayan akan mengurangi jumlah melaut untuk sementara waktu. Selain itu, kenaikan hargaharga barang secara umum akan membuat daya beli masyarakat melemah. Akibatnya, permintaan terhadap ikan di pasarakan menurun.

\section{PILIHAN-PILIHAN KEBIJAKAN}

Sejauh ini, model kompensasi yang biasa dilakukan hanya berbasis pendekatan konsumsi, yakni meningkatkan daya beli nelayan terhadap kenaikan konsumsi barang dan jasa akibat kenaikan harga BBM.Pendekatan berbasis konsumsi ini harus disertai juga dengan pendekatan produksi yang mampu mendorong masyarakat perikanan melakukan usaha.

Kebijakan yang dapat dilakukan pemerintah yang berhasil diidentifikasi dari berbagai sumber (Fauziyah, 2003; Purnomo, 2005; Pasaribu, 2008; Satria, 2009; Suryawati et al., 2012b) terkait upaya antisipasi kenaikan harga BBM atau penyaluran BBM bersubsidi diantaranya adalah:

a. Membangun lembaga kredit yang dimaksudkan untuk meningkatkan modal usaha melalui lembaga keuangan yang sudah terbentuk di masyarakat, seperti koperasi nelayan. Mekanisme ini dapat dipadukan dengan upaya pengembangan atau penguatan lembaga keuangan yang selama ini bermasalah. Dalam operasionalnya, subsidi individu dikumpulkan sebagai penyertaan modal dalam lembaga keuangan. Upaya ini merupakan langkah tepat jika dibandingkan membentuk lembaga keuangan baru yang memerlukan pembinaan dan pengawasan dari nol lagi. Sasaran dari program ini adalah kapal berukuran $10-20$ GT.

b. Mengoptimalkan fungsi SPDN yang menjamin kelangsungan suplai BBM di pusat-pusat kegiatan penangkapan tanpa adanya penambahan biaya lain-lain. Program ini dimaksudkan untuk meningkatkan layanan SPDN karena pada praktiknya nelayan tidak hanya terkendala dalam memperoleh $\mathrm{BBM} /$ solar, tetapi juga kesulitan memenuhi kebutuhan perbekalan untuk kegiatan penangkapan. Dalam operasionalisasinya, SPDN ini dapat bersinergi dengan lembaga kredit dimana nelayan dapat memperoleh kedua modal tersebut secara kredit yang selama ini dipenuhi dari warung (langgan) dan bakul (tengkulak).

c. Mengembangkan diversifikasi usaha perikanan tangkap ke arah usaha perikanan budidaya dan pengolahan hasil perikanan yang memiliki tingkat ketergantungan pada BBM rendah.

d. Efisiensi usaha penangkapan perikanan dalam hal efisiensi penggunaan BBM. Hal yang mungkin dilakukan adalah penggunaan alat penghemat BBM seperti EGB (Electronic Gas Booster). Upaya lainnya adalah memberlakukan transhipment, dimana BBM dapat dihemat karena ikan hanya diangkut oleh kapal pengangkut ikan saja. Kebijakan ini tentunya harus disertai dengan menghindari jangan sampai terjadi pelanggaran yaitu IUU fishing. 
e. Membiarkan perikananmengalamirasionalisasi secara alamiah. Pada saat terjadi kenaikan harga BBM, maka hanya nelayan-nelayan yang paling efisien (highliners) akan dapat bertahan dalam industri, sedangkan nelayan yang tidak efisien (marginal) menghentikan kegiatannya. Membiarkan kondisi seperti itu dapat bernilai positif karena itu akan membawa kepada efisiensi sumber daya. Namun, dampak ekonomi dan sosial akan sangat besar akan terjadi dalam jangka pendek, terutama untuk nelayan-nelayan marginal yang tersisih dari industri. Namun, keluarnya sebagian nelayan dari industri akan memberikan kesempatan kepada sumber daya untuk memulihkan stoknya sehingga dalam jangka panjang dapat diharapkan adanya perikanan yang berlangsung optimal, dengan tingkat keuntungan tertinggi

f. Mengupayakan rasionalisasi artifisial. Pemerintah mengalokasikan dana untuk mengalihkan kegiatan penangkapan yang tidak efisien ke aktivitas ekonomi yang lebih menguntungkan, misalnya: a) mengelompokkan sebagian nelayan kecil yang beroperasi di pantai yang telah overfishing kedalam kegiatan penangkapan menggunakan kapal lebih besar untuk menjangkau wilayah-wilayah under-utilized; dan b) Menerapkan buyback program (pembelian sarana produksi nelayan yang tidak efisien dari nelayan), dan mendorong mereka untuk memasuki usaha perikanan non-penangkapan (pasca panen, budidaya, jasa, dan sebagainya) maupun usaha non perikanan. Dana yang sangat besar akan diperlukan, namun dampak positif jangka panjang akan terjadi sebagaimana pada kebijakan rasionalisasi alamiah.

g. Program asuransi untuk nelayan yang merupakan pemberian jaminan bagi keluarga nelayan. Hal ini disebabkan tingginya risiko yang dihadapi nelayan saat melakukan kegiatan penangkapan. Mekanismenya dilakukan melalui lembaga penjamin dengan menarik iuran dari nelayan dengan nominal rupiah yang tidak memberatkan nelayan.

\section{ALTERNATIF SOLUSI DAN PILIHAN STARTEGI KEBIJAKAN}

Dalam tulisan ini, dilakukan analisis SWOT yang didasarkan pada asumsi bahwa strategi yang efektif adalah dengan memaksimalkan kekuatan (strengths) dan peluang (opportunities), serta meminimalkan kelemahan (weaknesses) dan ancaman (threats). Selanjutnya disusun ke dalam matriks SWOT untuk mencocokkan faktorfaktor eksternal dan internal usaha perikanan tangkap dalam menghasilkan alternatif strategi. Matriks tersebut mencakup strategi SO (Strength - Opportunities), WO (Weakness - Opportunities), ST (Strength - Threats) dan WT (Weakness Threats).

Strategi SO merupakan strategi yang memanfaatkan kekuatan internal usaha perikanan dalam meraih keuntungan dari peluang eksternal. Pertama adalah fasilitasi nelayan kecil (< $30 \mathrm{GT}$ ) dalam mendapatkan BBM bersubsidi. Kedua adalah mengoptimalkan kerjasama dengan pemerintah daerah dalam menciptakan inovasi subsidi BBM agar subsidi tersebut bisa menjangkau semua nelayan. Selanjutnya ketiga adalah mendorong, mempromosikan energi alternatif untuk membantu nelayan dalam meningkatkan efisiensi penggunaan BBM.

Strategi W-O adalah strategi yang bertujuan untuk mengatasi kelemahan usaha perikanan dengan memanfaatkan peluang yang ada. Pertama yang dapat diterapkan oleh usaha perikanan adalah meningkatkan infrastruktur untuk distribusi BBM subsidi untuk nelayan (kecil). Kedua yang dapat diterapkan oleh usaha perikanan adalah memperketat distribusi BBM subsidi untuk nelayan. Ketiga yang dapat diterapkan oleh usaha perikanan adalah menginovasi "model penjaminan" untuk distribusi BBM subsidi untuk nelayan kecil.

Strategi S-T adalah strategi yang menggunakan kekuatan usaha perikanan untuk menghindari ancaman dari luar. Pertama yang dapat diterapkan oleh usaha perikanan adalah kerjasama pihak terkait dengan nelayan untuk memberantas illegal fishing. Kedua yang dapat diterapkan oleh usaha perikanan adalah mempertimbangkan daerah over fishing untuk dijadikan daerah konservasi. Ketiga yang dapat diterapkan oleh usaha perikanan adalah mencari lokasi penangkapan baru untuk mengefisienkan konsumsi BBM.

Strategi W-T adalah strategi yang ditujukan untuk mengurangi kelemahan internal yang dimiliki dan menghindari ancaman eksternal yang ada. Pertama yang dapat dijalankan usaha perikanan 
adalah penggunaan mesin atau teknologi yang hemat bahan bakar. Kedua adalah penciptaan alternatif produk untuk bahan baku, perbekalan,dan perlengkapan sejenis yang lebih murah. Ketiga adalah usaha perikanan tidak mendapatkan subsidi dan mengikuti mekanisme pasar yang berlaku. Matriks SWOT untuk usaha perikanan tangkap secara lengkap disajikan pada Tabel 11.

Tabel 11. Matriks SWOT untuk Mengantisipasi Dampak Kenaikan Harga BBM pada Usaha Perikanan Tangkap.

Table 11. SWOT Matrix to Anticipate the Impact of Fuel Price Increase on Capture Fisheries.

\section{EFASIIFAS}

\section{Peluang /Opportunity}

1. Sumberdaya ikan pelagis besar masih bisa di manfaatkan IPelagic fish possible resources is still for increased fishing intensity

2. Kebijakan subsidi harga BBM untuk nelayan /Policy of fuel subsidy for fishermen

3. Ada kemungkinan energi alternatif yang dapat dikembangkan untuk perikanan tangkap/ Alternative energy is prospective for capture fishery

4. Nelayan kecil maupun besar dapat bertahan dengan kenaikan harga BBM sebelumnya/ Fishermen could stand the impact of the price increase in the past)

5. Kerjasama dengan daerah untuk inovasi subsidi BBM agar dapat menjangkau nelayan kecil /Cooperation with local government can reach small scale fishermen

\section{Kelemahan /Weaknesses}

1. Tenaga kerja untuk perikanan tangkap banyak /Availability of manpower in capture fishery is high

2. Kapal < 30 GT dan > 30 GT mempunyai peran penting dalam memenuhi kebutuhan protein $/<30 \mathrm{GT}$ and $>30 \mathrm{GT}$ vessels play important role in protein sufficiency

3. BBM merupakan kebutuhan terbesar $(60 \%)$ dari total kebutuhan operasional / Fuel Cost contributes $60 \%$ of operational costs)

4. BBM untuk nelayan masih diberikan harga subsidi / Fuel price is still subsidized

5. Permintaan ikan nasional dan international meningkat/ Domestic and international demand for fish is increasing.

6. Nelayan kecil sudah terbiasa membeli BBM di atas harga normal (Rp. 4.500/liter) dari SPBU /Small scale fishermen is accustomed with fuel price higher than the normal price

\section{Strategi SOI Strategy SO}

1. Fasilitasi nelayan kecil $(<30$ GT) dalam mendapatkan BBM bersubsidi /Facilitating small fishermen to get acces to subsidized fuel

2. Mengoptimalkan kerjasama dengan pemerintah daerah dalam menciptakan inovasi subsidi BBM agar subsidi tersebut bisa menjangkau semua nelayan /Optimizing cooperation with local government to improve accessof small fishermen to subsidized fuel.

3. Mendorong, mempromosikan energi alternatif untuk membantu nelayan dalam meningkatkan efisiensi penggunaan BBM/Promoting alternative energy to improve fuel use efficiency
1. Mutu hasil tangkapan kurang baik /Fish catch quality is low

2. Produksi hasil tangkapan semakin menurun /Fish catch is decreasing

3. Adanya penjualan ikan yang tidak dilaporkan oleh nelayan IUnreported catch exists)

4. Infrastruktur SPDN belum menjangkau semua nelayan di seluruh Indonesia /SPDN infrastructure does not reach all fishermen

5. Distribusi BBM subsidi untuk nelayan belum termonitor dengan baik/ Distribution of fuel subsidy is not well monitored.

6. Nelayan kecil jauh akses dari SPDN / Small scall fishermen has little acces to fuel station.

\section{Strategi WOI Strategy WO}

1. Meningkatkan infrastruktur untuk distribusi BBM subsidi untuk nelayan kecil/ Improving infrastructure to improve access of small fishermen to fuel

2. Memperketat distribusi BBM subsidi untuk nelayan/ Controling distribution of subsidized fuel

3. Menginovasi "model penjaminan" untuk distribusi BBM subsidi untuk nelayan kecil/Innovating insurance model for distribution of fuel subsidy. 
Lanjutan Tabel 11/Continue Table 11

\begin{tabular}{|c|c|c|}
\hline Ancaman/Threat & Strategi ST/Strategy ST & Strategi WT/Strategy WT \\
\hline $\begin{array}{l}\text { 1. Kenaikan harga BBM dan } \\
\text { perbekalan /Price of fuel and } \\
\text { fishing utilities increases } \\
\text { 2. Terjadinya overfishing } \\
\text { dibeberapa wilayah } \\
\text { penangkapan ikan/ } \\
\text { Overfishing occurs in a } \\
\text { number of fishing grounds } \\
\text { 3. Adanya illegal fishing yang } \\
\text { dilakukan oleh nelayan } \\
\text { asing/lllegal fishing by foreign } \\
\text { vessels } \\
\text { 4. Jarak fishing ground relatif } \\
\text { jauh /Fishing grounds are } \\
\text { located in relatively distant } \\
\text { areas } \\
\text { 5. Potensi terjadinya konflik } \\
\text { akibat tidak meratanya } \\
\text { distribusi BBM /Potential } \\
\text { conflict arise as fuel is not well } \\
\text { distributed }\end{array}$ & $\begin{array}{l}\text { 1. Kerjasama pihak terkait } \\
\text { dengan nelayan untuk } \\
\text { memberantas illegal fishing/ } \\
\text { Cooperation among relevant } \\
\text { parties to combat illegal } \\
\text { fishing } \\
\text { 2. Mempertimbangkan daerah } \\
\text { over fishing untuk dijadikan } \\
\text { daerah } \\
\text { konservasi/Considering } \\
\text { overfished grounds for } \\
\text { conservation areas } \\
\text { 3. Mencari lokasi penangkapan } \\
\text { baru untuk mengefisienkan } \\
\text { konsumsi BBM/Searching for } \\
\text { new fishing grounds to } \\
\text { improve fuel efficiency }\end{array}$ & $\begin{array}{l}\text { 1. Penggunaan mesin atau } \\
\text { teknologi yang hemat bahan } \\
\text { bakar /Introducing fuel } \\
\text { efficient engines or } \\
\text { technologies } \\
\text { 2. Alternatif produk untuk bahan } \\
\text { baku, perbekalan, dan } \\
\text { perlengkapan sejenis yang } \\
\text { lebih murah / Alternative } \\
\text { products for cheaper raw } \\
\text { materials and utilities } \\
\text { 3. Tidak ada subsidi dan } \\
\text { mengikuti mekanisme pasar } \\
\text { yang berlaku/Removing } \\
\text { subsidy and implanting } \\
\text { market mechanism }\end{array}$ \\
\hline
\end{tabular}

Sumber: Data diolah (2013) / Source: Processed data (2013)

Beberapa strategi yang disebutkan pada Tabel 10 (SO, WO, ST dan WT) tidak mengharuskan semuanya menjadi pilihan kebijakan. Dengan naiknya harga BBM maka usaha perikanan mengalami dampaknya. Hasil penelusuran studi berdasarkan pengalaman masa lalu tentang dampak kenaikan BBM pada usaha perikanan dapat dilihat pada Tabel 12.

Sementara itu, Tabel 13 ditampilkan untuk memberikan jabaran umum mengenai kebijakan antisipatif agar dampak kenaikan BBM yang tidak diharapkan tidak terjadi lagi di masa yang akan datang seperti dimaksud pada Tabel 12. Secara umum dampak kenaikan harga BBM pada usaha perikanan tangkap adalah kekurangan modal untuk biaya operasional, kesulitan penjualan, dan berkurangnya hari operasi melaut.

Kebijakan antisipatif terhadap dampak kebijakan kenaikan harga BBM, hendaknya mempertimbangkan berbagai aspek seperti aspek ekonomi, sosial, dampak lingkungan, keuangan dan keberlanjutan usaha. Pemilihan opsi kebijakan yang akan diimplementasikan perlu mempertimbangkan berbagai trade off di antara pilihan-pilihan tersebut. Tabel 14 di bawah ini menggambarkan garis besar dari tradeoff dimaksud. 
Tabel 12. Dampak Kenaikan Harga BBM pada Usaha Perikanan.

Table 12. Fuel Price Impact on Fisheries.

\begin{tabular}{ccc}
\hline & Kenaikan Harga & Referensi/ \\
Waktu/ Time & BBM/ & Fuel Price \\
Increase & $\begin{array}{c}\text { Dampak Pada Usaha Perikanan/ } \\
\text { Impact on Fisheries }\end{array}$ & $\begin{array}{c}\text { Refference } \\
\end{array}$ \\
\hline
\end{tabular}

1 Oktober Dari (from) Rp

(October) 2.100,- menjadi

$2005^{1} \quad$ (to) Rp 4.300,-

$(104,8 \%)$
Kekurangan modal untuk biaya operasional, karena harga BBM menyebabkan kenaikan harga-harga kebutuhan operasional penangkapan selain solar yaitu perbekalan (seperti es, oli, lauk pauk, dan sebagainya/ Deficit in financial source for operational costs because fuel price increase caused increases in prices of fishing utilities

Kesulitan penjualan karena nelayan menaikkan harga jual ikan hasil produksinya/ Difficulti in selling the fish because of higher fish selling price

Kesulitan bahan baku produksi untuk pengolahan ikan/ Difficulty in acquiring raw material for processing activities Perubahan kondisi teknologi budidaya dari intensif menjadi tradisional/Aquaculture technology decreased from intensive to traditional

Penurunan produksi perikanan budidaya tambak akibat kenaikan biaya produksi/ Decrease in pond fish production due to higher production costs Meningkatnya tindakan kriminalitas di laut seperti perampokan hasil tangkapan, perusakan kapal yang mengganggu kegiatan penangkapan/ Increase in crime incidents

\begin{tabular}{ll}
\hline $24 \mathrm{Mei}$ (May) & Dari (from) Rp \\
$2008^{2}$ & $4.300,-$ menjadi \\
& (to) $\mathrm{Rp} 5.500,-$
\end{tabular}
ikan sehingga kehidupan nelayan akan semakin berat/
Pasaribu (2008);

Fauziyah (2003) Meningkatnya biaya operasi penangkapan KKP (2008) Increase of operational cost Meningkatnya biaya produksi usaha budidaya KKP (2008) dan pengolahan hasil perikanan/ Increased production costs of aquaculture and fish processing

Berkurangnya hari operasi pengawasan KKP (2008) Anonim (2005) Purnomo (2005) sumberdaya kelautan dan perikanan/ Reduced operating days of resource monitoring and surveillance

'Peraturan Presiden No 55 Tahun 2005

${ }^{2}$ Peraturan Menteri Energi dan Sumberdaya Mineral Nomor 16 Tahun 2008 
Tabel 13. Kebijakan Antisipatif Menghadapi Kenaikan Harga BBM Pada Usaha Perikanan. Table 13. Anticipative Policies for Impact of Fuelprice Increase on Fisheries.

\begin{tabular}{|c|c|c|c|}
\hline $\begin{array}{l}\text { Dampak yang terjadi } \\
\text { akibat kenaikan BBM } \\
\text { / Fuel price impact }\end{array}$ & $\begin{array}{c}\text { Kebijakan } \\
\text { antisipatif / } \\
\text { Antisipative policy }\end{array}$ & & Deskripsi / Description \\
\hline $\begin{array}{l}\text { Kekurangan modal } \\
\text { untuk biaya } \\
\text { operasional (lack of } \\
\text { capital for operational } \\
\text { costs) }\end{array}$ & $\begin{array}{l}\text { Pemberian subsidi } \\
\text { pembelian BBM } \\
\text { (Providing subsidy } \\
\text { for fuel purchase) }\end{array}$ & ० & $\begin{array}{l}\text { Pemerintah memberi kompensasi sebesar } \\
\text { jumlah kenaikan harga BBM untuk setiap } \\
\text { pembelian satu unit volume BBM } \rightarrow \\
\text { diperlukan dana yang sangat besar } \\
\text { (government provides compensation equals to } \\
\text { theamount of of price increase } \rightarrow \text { need huge } \\
\text { financial resources) } \\
\text { Kebijakan ini akan memberikan dampak sosial } \\
\text { yang sangat positif untuk jangka pendek } \\
\text { karena dapat menekan penurunan pendapatan } \\
\text { dan keuntungan dari kegiatan penangkapan } \\
\text { (This policy will positive impact on social aspect } \\
\text { in the short term because it can prevent } \\
\text { income decrease and profit of capture fisheries } \\
\text { activity) } \\
\text { Namun, kebijakan tersebut akan kian } \\
\text { memperberat tekanan ekologis pada sebagian } \\
\text { wilayah penangkapan sehingga dalam jangka } \\
\text { panjang perikanan makin tidak produktif, } \\
\text { keuntungan usaha makin kecil, dan secara } \\
\text { sosial nelayan akan makin berat (However, } \\
\text { those policy would give ecological pressure on } \\
\text { fishing ground, fisheries will not productive in } \\
\text { the future, profit will decrease, give more } \\
\text { presure to social life of fishers) } \\
\text { Dalam pelaksanaannya harus bekerjasama } \\
\text { dengan pemerintah daerah untuk } \\
\text { memfasilitasi nelayan terutama nelayan kecil } \\
\text { untuk mendapatkan BBM bersubsidi (the } \\
\text { implementation will need cooperation with } \\
\text { local government to facilitate fishers especially } \\
\text { traditional fishers to find out the subsidized } \\
\text { fuel } \\
\text { Diperlukan dukungan infrastruktur di daerah } \\
\text { terutama daerah terpencil. Hal ini bertujuan } \\
\text { untuk mendekatkan akses nelayan kepada } \\
\text { BBM bersubsidi (need infrastructure support } \\
\text { particularly in the isolated region to improve } \\
\text { access for fishers to those fuel) } \\
\text { Kemudian perlu memperketat monitoring } \\
\text { distribusi BBM bersubsidi untuk nelayan, agar } \\
\text { konsumsi BBM dapat didistribusikan sesuai } \\
\text { dengan kebutuhan nelayan pada masing- } \\
\text { masing skala usaha (need stronger monitoring } \\
\text { on fuel distribution for fishers) }\end{array}$ \\
\hline
\end{tabular}




\section{Lanjutan Tabel 13/Continue Table 13}

\begin{tabular}{|c|c|c|c|}
\hline $\begin{array}{l}\text { Dampak yang terjadi } \\
\text { akibat kenaikan BBM } \\
\text { / Fuel price impact }\end{array}$ & $\begin{array}{c}\text { Kebijakan } \\
\text { antisipatif / } \\
\text { Antisipative policy }\end{array}$ & & Deskripsi / Description \\
\hline $\begin{array}{l}\text { Kesulitan penjualan } \\
\text { hasil tangkapan } \\
\text { (dfficulty in selling the } \\
\text { catch) }\end{array}$ & $\begin{array}{l}\text { Penjaminan harga } \\
\text { penjualan yang } \\
\text { dikaitkan dengan } \\
\text { kualitas hasil } \\
\text { tangkapan } \\
\text { (implementing } \\
\text { selling price } \\
\text { scheme which is } \\
\text { associated with } \\
\text { fish quality) }\end{array}$ & o & $\begin{array}{l}\text { Pemerintah memberikan kompensasi terhadap } \\
\text { selisih antara harga 'wajar' dan harga yang } \\
\text { berlaku berdasarkan kriteria mutu produk } \\
\text { (government provides compensation for the } \\
\text { residual between normal price and price that } \\
\text { associated with quality) } \\
\text { Dengan kebijakan ini, diharapkan masing- } \\
\text { masing nelayan akan mendapatkan insentif } \\
\text { yang besar untuk hanya mendaratkan ikan-ikan } \\
\text { berkualitas, dengan mendapatkan imbalan } \\
\text { harga yang setimpal, sehingga mendapatkan } \\
\text { keuntungan yang cukup (this policy will } \\
\text { motivate fishers to produce quality fish and get } \\
\text { more profit) } \\
\text { Sebagian nelayan (meskipun tidak sebanyak } \\
\text { pada kebijakan rasionalisasi) akan keluar dari } \\
\text { industri sehingga dapat diharapkan akan } \\
\text { terjadinya dampak positif jangka panjang yang } \\
\text { cukup besar (a number of fishers will be } \\
\text { dislocated, leading to long run positive effect to } \\
\text { the resource) }\end{array}$ \\
\hline $\begin{array}{l}\text { Berkurangnya hari } \\
\text { operasi melaut } \\
\text { (decreasing on fishing } \\
\text { day) }\end{array}$ & $\begin{array}{l}\text { Pembatasan waktu } \\
\text { operasi melaut dan } \\
\text { wilayah jangkuan } \\
\text { operasi (Limitation } \\
\text { on fishing day and } \\
\text { fishing ground) }\end{array}$ & ० & $\begin{array}{l}\text { Pemerintah menetapkan tingkat upaya optimal } \\
\text { (misal dituangkan dalam jumlah hari melaut } \\
\text { dan kuota untuk masing-masing wilayah } \\
\text { penangkapan) (government establish optimal } \\
\text { effort level (i.e, based on fishing day and quota } \\
\text { for every fishing region) } \\
\text { Diperlukan dana yang cukup besar, terutama } \\
\text { untuk perencanaan dan pengawasan } \\
\text { pelaksanaan kebijakan (big financial support is } \\
\text { needed, especially for policy planning and } \\
\text { enforcement) } \\
\text { Diperkirakan akan terjadi dampak positif yang } \\
\text { cukup besar dalam jangka panjang meskipun } \\
\text { mungkin tidak sebesar dampak positif pada } \\
\text { kebijakan rasionalisasi, terutama karena } \\
\text { besarnya potensi kegagalan dalam } \\
\text { pengawasan pelaksanaan kebijakan } \\
\text { pembatasan upaya. (will create positive impact } \\
\text { in the long term even it might not give positive } \\
\text { impact as on rationalizing policy, especially } \\
\text { because failure potency on effort limitation } \\
\text { policy) }\end{array}$ \\
\hline
\end{tabular}


Tabel 14. Analisis Trade Off Pilihan Kebijakan Mengantisipasi Dampak Kenaikan Harga BBM dan Konsekuensinya dilihat dari Berbagai Aspek.

Table 14. Trade Off Analysis of Policy Options in Anticipating the Impact of Fuel Price.

\begin{tabular}{|c|c|c|c|c|c|}
\hline \multirow{2}{*}{$\begin{array}{l}\text { Kebijakan Antisipatif/ } \\
\text { Anticipatory Policy }\end{array}$} & \multicolumn{5}{|c|}{ Dampak /Impact } \\
\hline & $\begin{array}{l}\text { Ekonomi/ } \\
\text { Economy }\end{array}$ & $\begin{array}{l}\text { Sosial/ } \\
\text { Social }\end{array}$ & $\begin{array}{l}\text { Lingkungan/ } \\
\text { Environment }\end{array}$ & $\begin{array}{l}\text { Keuangan/ } \\
\text { Financial }\end{array}$ & $\begin{array}{c}\text { Keberlanjutan/ } \\
\text { Sustainability }\end{array}$ \\
\hline $\begin{array}{l}\text { Pemberian subsidi pembelian } \\
\text { BBM/Subsidy for fuel purchase }\end{array}$ & +++ & + & + & + & + \\
\hline $\begin{array}{l}\text { Penjaminan harga penjualan } \\
\text { yang dikaitkan dengan kualitas } \\
\text { hasil tangkapan/Quality pricing } \\
\text { scheme }\end{array}$ & +++ & ++ & ++ & ++ & ++ \\
\hline $\begin{array}{l}\text { Pembatasan waktu operasi } \\
\text { melaut dan wilayah jangkuan } \\
\text { operasi /Raionalization of } \\
\text { fishing time and ground }\end{array}$ & + & + & +++ & + & +++ \\
\hline
\end{tabular}

Sumber: Data diolah (2013) / Source : Processed data (2013)

\section{PENUTUP}

Kebijakan penghapusan subsidi BBM berdasarkan kondisi yang pernah terjadi sebelumnya ditandai dengan melambungnya harga BBM yang berdampak terhadap perubahan kinerja pada semua aspek ekonomi, termasuk sektor perikanan. Aspek ekonomi yang dimaksud adalah pengurangan keuntungan nelayan (7,89-31,38 $\%)$ dan peningkatan biaya operasional melaut $(12,14-22,69 \%)$.

Pada usaha perikanantangkap, dampak kenaikan harga BBM akan menyebabkan menurunnya rasio penerimaan dan biaya $(6,76$ $14,91 \%$ ) walaupun di sisi lain bila terjadi kenaikan harga jual ikan sebesar $15 \%$. Fenomena ini menunjukkan bahwa kenaikan biaya produksi akibat kenaikan harga BBM yang dialami oleh pelaku usaha perikanan tangkap, dalam hal ini adalah nelayan, sepenuhnya dibebankan ke mereka dengan cara menaikkan hasil jual.

Dampak kenaikan harga BBM pada usaha perikanan tangkap diantaranya adalah kekurangan modal untuk biaya operasional, kesulitan penjualan hasil tangkapan dan berkurangnya hari operasi melaut. Oleh karena itu pilihan kebijakan yang dapat dilakukan untuk mengantisipasinya adalah pemberian subsidi pembelian BBM, penjaminan harga penjualan yang dikaitkan dengan kualitas hasil tangkapan dan pembatasan waktu operasi melaut dan wilayah jangkuan operasi.
Beberapa hal penting untuk diperhatikan dalam mengantisipasi dampak kenaikan harga BBM pada usaha perikanan diantaranya adalah: 1) Mengoptimalkan kerjasama dengan pemerintah daerah untuk memfasilitasi nelayan terutama nelayan kecil untuk mendapatkan BBM bersubsidi. Alasannya adalah selama ini mereka belum banyak merasakan subsidi tersebut karena BBM dibeli dari SPBU dengan harga yang sama (umum). Selain itu, pemerintah dapat berperan serta untuk menjamin BBM subsidi terdistribusi dengan baik kepada nelayannelayan kecil; 2) Meningkatkan infrastruktur di daerah terutama daerah terpencil. Hal ini bertujuan untuk mendekatkan akses nelayan kepada BBM bersubsidi; dan 3) Memperketat monitoring distribusi BBM bersubsidi untuk nelayan, agar konsumsi BBM dapat didistribusikan sesuai dengan kebutuhan nelayan pada masing-masing skala usaha.

Pilihan kebijakan tersebut dimaksudkan untuk mempertahankan penerimaan relatif yang diterima masyarakat perikanan (nelayan, pembudidaya dan pengolah), maka perlu adanya kebijakan dari pemerintah terkait harga produk perikanan. Harapannya, pelaku usaha perikanan dapat mencapai keuntungan yang layak dan harga stabil perlu diupayakan dalam konteks peningkatan kesejahteraan rumah tangga perikanan. 


\section{DAFTAR PUSTAKA}

Balai Besar Penelitian Sosial Ekonomi Kelautan dan Perikanan [BBPSEKP]. 2012. Panel Kelautan dan Perikanan Nasional (Panelkanas) dan Analisis Dinamika NIlai Tukar dalam Mendukung Ketahanan Pangan untuk Pengentasan Kemiskinan. Laporan Akhir Kegiatan Penelitian Tahun 2012. Jakarta: Balai Besar Penelitian Sosial Ekonomi Kelautan dan Perikanan BalitbangKP - KKP.

Fauziyah, D. 2003. Dampak Kenaikan Harga Bahan Bakar Minyak terhadap Pendapatan Usaha Nelayan Gill Net dan Rawai di Pelabuhan Perikanan Nusantara Palabuhanratu, Sukabumi, Jawa Barat.Skripsi. Bogor: Program Studi Manajemen Bisnis dan Ekonomi Perikanan - Kelautan, Jurusan Sosial Ekonomi Perikanan dan Kelautan, Fakultas Perikanan dan IImu Kelautan. Institut Pertanian Bogor.

Pasaribu, L. 2008. Dampak Kenaikan Harga BBM (Solar) terhadap Usaha Penangkapan Ikan dengan Pukat Cincin. Skripsi. Medan: Program Studi Agribisnis, Departemen Sosial Ekonomi Pertanian, Fakultas Pertanian. Universitas Sumatera Utara.
Purnomo, A.H. 2005. Pertimbangan untuk Pemilihan Kebijakan Alternatif Terkait dengan Kenaikan Harga BBM. Bahan yang Dipersiapkan untuk Paparan Kepala Badan Riset Kelautan dan Perikanan. Jakarta: BRKP KKP.

Satria, A. 2009. Ekologi Politik Nelayan. Yogyakarta: LKIS.

Suryawati, S.H., R. Muhartono, dan E.S. Luhur. 2012b. Potensi Kebijakan Subsidi BBM Berbasis Pendaratan Hasil Tangkap Ikan. Laporan Teknis Kajian Khusus ProgramProgram Pembangunan Kelautan dan Perikanan. Jakarta: Balai Besar Penelitian Sosial Ekonomi Kelautan dan Perikanan BalitbangKP - KKP.

Suryawati, S.H., R. Muhartono, E.S. Luhur, A.H. Purnomo dan N.T. Bualangi. 2012a. Kajian Kelayakan Pengembangan Energi Berbasis Sumberdaya Kelautan dan Efisiensi Penggunaan Energi dalam Usaha-Usaha Perikanan. Laporan Akhir Kegiatan Penelitian. Jakarta: Balai Besar Penelitian Sosial Ekonomi Kelautan dan Perikanan BalitbangKP - KKP. 